\title{
Microencapsulation of Anchovy Fish Oil (Engraulis encrasicolus) with Fish Protein (Equulites klunzingeri) Isolate: Nutritional Assessment
}

\author{
Gülsün Özyurt ${ }^{1, *} \mathbb{0}$, Ahmet Faruk Yeşilsu² \\ ${ }^{1}$ University of Cukurova, Faculty of Fisheries, Department Seafood Processing Technology, Adana, Turkey. \\ ${ }^{2}$ Central Fisheries Research Institute, Department of Food Technology, 61250, Trabzon, Turkey.
}

\section{How to cite}

Özyurt, G., Yeşilsu, A.F. (2021). Microencapsulation of Anchovy Fish Oil (Engraulis encrasicolus) with Fish Protein (Equulites klunzingeri) Isolate: Nutritional Assessment. Aquatic Food Studies, 1(1), AFS16. https://doi.org/10.4194/AFS16

\section{Article History \\ Received 18 June 2021 \\ Accepted 13 July 2021 \\ First Online 14 July 2021 \\ Corresponding Author \\ Tel.: +903223386084 \\ E-mail: beklevik@cu.edu.tr}

\section{Keywords}

Microencapsulation

Spray drying

Fish protein isolate

Fish oil

Amino acid composition

\begin{abstract}
Fish protein isolates extracted from underutilised fish species were used for coating material of anchovy oils and their nutritive value was investigated in this study. For this purpose, Klunzinger's ponyfish (Equulites klunzingeri) proteins were extracted by using $\mathrm{pH}$ shifting process. Micro particles were prepared with anchovy oil (Engraulis encrasicolus) as core material (10\%), and as wall materials a ratio of $5 \%$ and $10 \%$ fish protein isolate (FPI) was used. Maltodextrin (DE: 18:20) was added to both groups in a ratio of $10 \%$. The emulsions were fed immediately into a Buchi Mini Spray Dryer (B290, Switzerland). The inlet temperatures, feed rate and aspiration rate were maintained at $160{ }^{\circ} \mathrm{C}, 15 \mathrm{~mL} / \mathrm{min}$ and $35 \mathrm{~m}^{3} / \mathrm{h}$, respectively. The lipid, protein and moisture contents of anchovy oil microcapsules containing 5\% FPI and 10\% FPI were found as $43.76-43.09 \%, 4.34-9.82 \%$ and $3.95-3.92 \%$, respectively. The main amino acids in microcapsule samples were lysine, glutamic acid, and leucine which constituted in the range of $349-578 \mathrm{mg} / 100 \mathrm{~g}$ sample for microcapsules containing $5 \%$ $\mathrm{FPI}$, and $805-1547 \mathrm{mg} / 100 \mathrm{~g}$ sample for microcapsules containing $10 \% \mathrm{FPI}$. In addition to that, essentials and non-essential amino acids (E/NE) ratio for microencapsulated fish oil with $5 \% \mathrm{FPI}$ and $10 \% \mathrm{FPI}$ were determined 0.92 and 0.95 , respectively. As a result of this study, it can be concluded that the addition of fish protein isolate enhanced the nutritive value of microencapsulated fish oil.
\end{abstract}

\section{Introduction}

Fish oils are rich in long-chain w3-series fatty acids that have proven health-worthy, but are highly sensitive to lipid oxidation. Traditionally, they are used for healthy diets, and there is a growing interest of consumers for these oils in industrial foods. It is emphasized that the regular consumption of fish oil can provide a remedy to the problem of the micronutrient deficiency and thus significantly reduces the quantity of nutrition-related diseases (cardiovascular, neurodegenerative, oncological and mental diseases, etc.). It has been recommended by the Food and Agriculture Organization (FAO) and World Health Organization (WHO) that people consume $0.25-2 \mathrm{~g}$ of EPA+DHA per day for a healthy and balanced diet (FAO-WHO, 2010). On the other hand, The American Heart Association (AHA) recommends higher rates such as 2-4 g EPA+DHA intake per day for hypertriglyceridemic patients (Kris-Etherton et al., 2003). Nowadays, consuming higher $\omega-6$ than $\omega$ 3 , as is mostly happening in modern westernized diet styles, has been shown to exert an adverse effect on human health (Mariamenatu and Abdu, 2021). Therefore, dietary supplementation of $\omega 3$ fatty acids seems to be an alternative way to meet of these fatty acids by many consumers, and there has been an increasing consumer demand for foods enriched with especially EPA and DHA fatty acids.

The smell and taste of fish oils limit their usage in foods. Microencapsulation technology is the most 
effective method for the solution of these problems. The microencapsulation technique is a particular method used not only to convert liquids into solid materials, but also to add functionality or enhanced oxidative stability to components. Widespread use of this technique in the industry is spray drying, as it provides the advantage of low-cost commercial processing in large-scale production.

The selection of the appropriate coating material is the first important step in the microencapsulation process. The features sought in the wall material are that it is highly soluble in water, inert to active components, stabilized internal material, inexpensive and easily available. In practice, it may be preferred to mix more than one material because a single coating material does not meet all these features. Proteins are excellent wall materials for encapsulation using spray drying due to their functional properties. Proteins, in particular whey protein and sodium caseinate, have been highly studied as oil encapsulates due to their amphiphilic characteristics, which facilitate emulsion formation, enhance stability and produce desired physicochemical properties. In addition, although there are reports that food proteins such as soy proteins, milk proteins and egg proteins can be used as coating materials in microencapsulation technology, research on fish proteins is quite insufficient.

Process, such as surimi production, hydrolysate production or $\mathrm{pH}$ shifting method, can be selected for protein recovery from fish with low economic value. The $\mathrm{pH}$ shifting method enables efficient recovery of high quality fish protein, thus they can be successfully integrated into food products on the market. Although there are many studies on the application of the protein isolates from low economic valued fish in different food systems, such as fish ball, fish sausage (Ozyurt et al., 2019; Shaviklo, and Etemadian, 2019; Khan et al., 2020) the studies on fish protein isolates obtained by $\mathrm{pH}$ shifting for use as coating material, especially in fish oil microencapsulation, are limited. In this study, fish protein isolates extracted from underutilised fish species were used for coating material of anchovy oils and their nutritive value was investigated.

\section{Materials and Methods}

Klunzinger's ponyfish (Equulites klunzingeri) which is a discarded fish was caught by the staff of the Fisheries Faculty University of Çukurova in the Northeast Mediterranean Sea, and their proteins were extracted by using $\mathrm{pH}$ shifting process according to Hultin and Kelleher (2001) method. Klunzinger's ponyfish (3.65 \pm 1.5 $g$ average weight) samples were ground and homogenized for $1 \mathrm{~min}$ on a Waring blender (Waring Products, Torrington, Connecticut, USA) with cold distilled water at 1:6 ratios $(\mathrm{g}: \mathrm{ml})$. The $\mathrm{pH}$ of the solution was adjusted to 11 by adding $2 \mathrm{M} \mathrm{NaOH}$ and then homogenates were centrifuged at $13000 \mathrm{x}$ g (Sigma 16 SK, Germany) for $20 \mathrm{~min}$ at $4^{\circ} \mathrm{C}$. After the centrifugation, the homogenate was separated into three layers as a top (fish oil), middle (fish muscle protein solution) and bottom (bones, skin, scale, etc.). The middle phase was then filtered through a double layer of cheesecloth. The $\mathrm{pH}$ of the middle phase was adjusted to 5.5 by adding 2 $\mathrm{M} \mathrm{HCl}$ for isoelectrically precipitating fish proteins. Then the precipitated protein was centrifuged for $20 \mathrm{~min}$ at $13000 \times$ g at $4^{\circ} \mathrm{C}$ to set the aggregated proteins. After the second centrifuging step, precipitated and de-watered fish protein, which was called as fish protein isolates (FPI), was collected and stored at $-18^{\circ} \mathrm{C}$ until used.

Microparticles were prepared with anchovy oil (Engraulis encrasicolus) as core material (10\%), and as wall materials a ratio of $5 \%$ and $10 \%$ fish protein isolate (FPI) was used. Maltodextrin (DE: 18:20) was added to both groups in a ratio of $10 \%$. Before the emulsion, the FPI was dissolved in distilled water and $\mathrm{pH}$ was adjusted to 9 by adding $2 \mathrm{M} \mathrm{NaOH}$. The wall solutions were kept in benmari $\left(50^{\circ} \mathrm{C}\right)$ for one hour prior to emulsification. After cooling, fish oil was added and homogenized at $14000 \mathrm{rpm}$ for $10 \mathrm{~min}$ in ultra-turrax. The emulsions were fed immediately into a Buchi Mini Spray Dryer (B290, Switzerland). The inlet temperatures, feed rate and aspiration rate were maintained at $160^{\circ} \mathrm{C}, 15 \mathrm{~mL} / \mathrm{min}$ and $35 \mathrm{~m}^{3} / \mathrm{h}$, respectively.

\section{Proximate and Amino Acid Composition Analyses}

Moisture and crude ash content of microencapsulated fish oils with 5\% FPI and 10\% FPI were detected in an oven at $103^{\circ} \mathrm{C}$ and $550 \% \mathrm{C}$, respectively until the weight became constant. Lipid content was detected according to procedure of Bligh and Dyer (1959) and crude protein was found by Kjeldahl's method (AOAC 1999). Amino acid compositions of microencapsulated fish oils were detected by the MAM (Food Institute of Marmara Research Centre), TUBITAK (Scientific and Technological Research Council of Turkey). A Shimadzu 20 series ultrafast liquid chromatography with UV detection was used. The method was adapted from literature and modified by TUBITAK MAM (Dimova, 2003). Carbohydrate content was calculated by difference.

\section{Statistical Analyses}

All data were subjected to analysis of variance (one-way ANOVA), at 5\% confidence level using t-test.

\section{Results and Discussion}

Proximate and amino acid compositions of microencapsulated anchovy oil prepared with different rates of fish protein isolate are given in Table 1 and 2 . The moisture, lipid and protein contents of anchovy oil microcapsules containing 5\% FPI and 10\% FPI were found as $3.95-3.92 \%, 43.76-43.09 \%$, and $4.34-9.82 \%$, respectively. It is known that moisture content greatly influences physical, chemical, and microbial stability of 
Table 1. Proximate composition of microencapsulated fish oils (\%)

\begin{tabular}{lcc}
\hline & $5 \% \mathrm{FPI}$ & $10 \% \mathrm{FPI}$ \\
\hline Moisture & $3.95 \pm 0.03^{\mathrm{x}}$ & $3.92 \pm 0.02^{\mathrm{x}}$ \\
Ash & $0.19 \pm 0.03^{\mathrm{x}}$ & $0.19 \pm 0.02^{\mathrm{x}}$ \\
Lipid & $43.76 \pm 3.37^{\mathrm{x}}$ & $43.09 \pm 5.63^{\mathrm{x}}$ \\
Protein & $4.34 \pm 0.02^{\mathrm{x}}$ & $9.82 \pm 0.2^{\mathrm{y}}$ \\
Carbohydrate (Maltodextrin) & $47.76^{\mathrm{x}}$ & $42.98^{\mathrm{y}}$ \\
\hline
\end{tabular}

The values are expressed as mean and standard deviation, $\mathrm{n}=3$.

Means followed by different superscript letters are significantly different $(P<0.05)$

FPI: fish protein isolate

Table 2. Amino acid composition of microencapsulated fish oils ( $\mathrm{mg} / 100 \mathrm{~g})$

\begin{tabular}{lcc}
\hline & $5 \% \mathrm{FPI}$ & $10 \% \mathrm{FPI}$ \\
\hline Aspartic acid & $278 \pm 91.92^{\mathrm{x}}$ & $797 \pm 14.14^{\mathrm{y}}$ \\
Glutamic acid & $431 \pm 38.89^{\mathrm{x}}$ & $1227 \pm 11,31^{\mathrm{y}}$ \\
Serine & $138 \pm 2.12^{\mathrm{x}}$ & $379 \pm 0.00^{\mathrm{y}}$ \\
Glycine & $156 \pm 0.71^{\mathrm{x}}$ & $347 \pm 0.71^{\mathrm{y}}$ \\
Arginine & $166 \pm 4.24^{\mathrm{x}}$ & $500 \pm 4.24^{\mathrm{y}}$ \\
Alanine & $216 \pm 16.97^{\mathrm{x}}$ & $511 \pm 7.78^{\mathrm{y}}$ \\
Proline & $208 \pm 29.70^{\mathrm{x}}$ & $417 \pm 5.66^{\mathrm{y}}$ \\
Tyrosine & $116 \pm 7.78^{\mathrm{x}}$ & $276 \pm 2.12^{\mathrm{y}}$ \\
Histidine & $72 \pm 0.71^{\mathrm{x}}$ & $173 \pm 1.41^{\mathrm{y}}$ \\
Threonine & $138 \pm 0.71^{\mathrm{x}}$ & $382 \pm 14.14^{\mathrm{y}}$ \\
Valine & $70 \pm 8.49^{\mathrm{x}}$ & $269 \pm 4.24^{\mathrm{y}}$ \\
Methionine & $21 \pm 0.00^{\mathrm{x}}$ & $233 \pm 0.71^{\mathrm{y}}$ \\
Isoleucine & $170 \pm 4.24^{\mathrm{x}}$ & $383 \pm 2.12^{\mathrm{y}}$ \\
Leucine & $349 \pm 13.44^{\mathrm{x}}$ & $805 \pm 3.54^{\mathrm{y}}$ \\
Phenylalanine & $180 \pm 9.90^{\mathrm{x}}$ & $428 \pm 2.83^{\mathrm{y}}$ \\
Lysine & $578 \pm 22.63^{\mathrm{x}}$ & $1547 \pm 14.85^{\mathrm{y}}$ \\
E/NE & 0,92 & 0,95 \\
\hline
\end{tabular}

The values are expressed as mean and standard deviation, $n=3$. Means followed by different superscript letters are significantly different $(P<0.05)$. E/NE: Essential Amino Acid/Non Essential Amino Acid Ratio.

foods. Moisture content for microencapsulated fish oil is particularly a significant parameter, as high water activity increases lipid oxidation. In addition to that, at high humidity levels, the wall material transforms from the glassy state to a high molecular mobility amorphous rubbery state, leading to the release of microencapsulated oil during storage (Charles et al., 2021; Velasco et al., 2000). The moisture content of microencapsulated oil has been reported by some researchers in the range of $0.24-4.25 \%$ (Ashokkumar et al., 2018; Charles et al., 2021). Generally, the food industry suggests a maximum moisture level for the dry powder as 3-4\% (Klinkesorn et al., 2006). The results of this study for both groups were lower than the maximum moisture content limit (set below 4\%) for dry powdered food products. Crude ash content was found at $0.19 \%$ for both groups. The calculated carbohydrate content of the microencapsulated fish oils was mainly due to the added maltodextrin. Therefore, it was found in range of $47.76 \%$ for $5 \% \mathrm{FPI}$ group and $42.98 \%$ for the $10 \%$ FPI group.

The lipid content of microencapsulated fish oils was $43.76 \%$ for $5 \% \mathrm{FPI}$ and $43.09 \%$ for $10 \% \mathrm{FPI}$. It is an expected result since the lipid ratio was formulated to be $1 / 3$ of the dry matter ratio in the emulsion. As for protein content of microencapsulated fish oils, the addition rate of fish protein was reflected in the protein content of the microcapsules. Accordingly, it was determined that the protein content was $4.34 \%$ in the $5 \% \mathrm{FPI}$ added to group, while protein content was $9.82 \%$ in the $10 \% \mathrm{FPI}$ added group.

The amino acid composition of fish protein isolate used in this study was shown in Figure 1. The main amino acids of Klunzinger's ponyfish protein isolate extracted by $\mathrm{pH}$ shifting method were lysine, glutamic acid, leucine, threonine and alanine. These findings were in accordance with Özyurt et al (2015) who reported that leucine, threonine and alanine were basic amino acids in Klunzinger's ponyfish isolate produced with $\mathrm{pH}$ shifting method. Lysine and methionine, which are highly essential for human, were found to be 4162 and $788 \mathrm{mg} / 100 \mathrm{~g}$, respectively. After spray drying proses, the main amino acids of microencapsulated fish oil were also lysine, glutamic acid, and leucine (Table 2). Following these amino acids, aspartic acid, arginine and alanine were detected in significant amounts, while threonine was not existed in this sequence after microencapsulation. Therefore, it can be concluded that the most affected amino acid by heat treatment was threonine. Kaczmarek et al. (2013) studied the effect of 


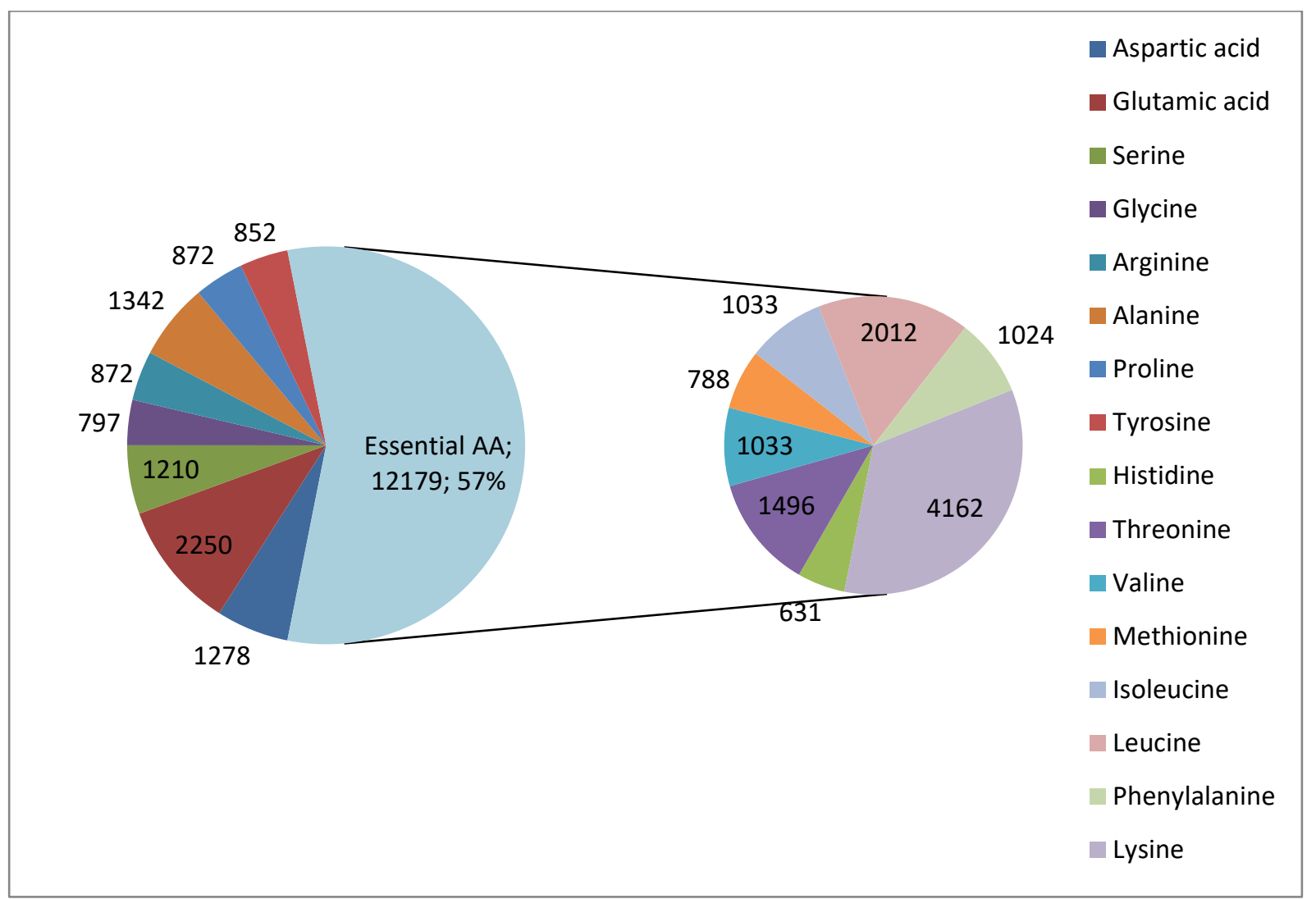

Figure 1. Amino acid composition of fish protein (Equulites klunzingeri) isolate added in microencapsulation of fish oil. The values are expressed as mean value $(\mathrm{mg} / 100 \mathrm{~g}), \mathrm{n}=3$.

oven drying at 60,100 and $140{ }^{\circ} \mathrm{C}$ on the amino acids. It was found that the most affected amino acids by the heat treatment were cysteine, tyrosine, threonine, glycine, isoleucine, serine and aspartic acid. In addition to that, the researchers reported that the mechanisms involved in the denaturation of protein during drying and heat treatments are still unclear. Similarly, in this study, it can be concluded that besides the proportional change in all amino acids, there was also a decrease with the effect of spray drying.

The protein quality of food can be assessed using the ratio between essential and non-essential amino acids ( $E / N E$ ). The ratio of $E / N E$ was determined to be 1.29 for fish protein isolate extracted $\mathrm{pH}$ shifting method in this study. Özyurt et al. (2015) found 0.95 $\mathrm{E} / \mathrm{NE}$ for the raw Klunzinger's pony. They reported that the ratios of $E / N E$ in freeze dried alkali-aided protein isolate and acid-aided protein isolate of Klunzinger's ponyfish were also found to be 0.90 and 0.81 , respectively. In this study, E/NE ratio for microencapsulated fish oil with 5\%FPI and 10\% FPI were determined as 0.92 and 0.95 , respectively. These ratios were considerably higher than those of many unprocessed fish that previously reported by some researchers (Iwasaki and Harada, 1985; Özyurt and Polat, 2006; Mol et al., 2008; Gómez-Limia et al., 2021). These results indicated that ponyfish isolate has well balanced protein thanks to favourable E/NE ratio, and may be considered as a nutrient-rich coating material for the microencapsulation process. In our previous study (Ozyurt et al., 2020), it was found that the addition of fish protein isolate in the wall material did not adversely affect the lipid stability of fish oil microcapsules. Based on these data, it can be concluded that fish protein isolates can be used as a wall material for microencapsulation of fish oil and have a high potential for application as a nutraceutical agent in food systems.

\section{Ethical Statement}

This article does not contain any studies involving animals performed by any of the authors.

\section{Funding Information}

There is no any funding institution for this study.

\section{Author Contribution}

GÖ: Conceptualization, Analysis, Methodology, Writing -review and editing; AFY: Analysis, Methodology, Statisctical Analysis 


\section{Conflict of Interest}

There is no conflict of interest.

\section{References}

Aitta, E. (2019). Product development using protein isolate produced by $\mathrm{pH}$-shift process from Baltic herring (Clupea harengus membras). Master's thesis in Technology University of Turku Department of Biochemistry Master's Degree Programme in Food Development, 60 pages.

AOAC (1999). Official method 981.10 crude protein in meat. In Meat and Meat Products, vol. II. 16th ed., Chapter 39 (P. Cunniff, ed.) pp. 1-15, Official Methods of Analysis of the AOAC International, Gaithersburg, MD.

Ashokkumar, C., Murugan, B., Baskaran, D., Veerapandian, V., \& Karthiayani, A. (2018). Effect of Wall Materials and Inlet Air Temperatures on Physical Properties of Microencapsulated of Olive Oil Powder. Int. J. Curr. Microbiol. App. Sci., 7(5), 2391-2402. https://doi.org/10.20546/ijcmas.2018.705.275

Bligh, E. G., \& Dyer, W. J. (1959). A rapid method of total lipid extraction and purification. Canadian Journal of Biochemistry and Physiology, 37(8), 911-917. https://doi.org/10.1139/o59-099

Charles, A. L., Abdillah, A. A., Saraswati, Y. R., Sridhar, K., Balderamos, C., Masithah, E. D., \& Alamsjah, M. A. (2021). Characterization of freeze-dried microencapsulation tuna fish oil with arrowroot starch and maltodextrin. Food Hydrocolloids, 112, 106281. https://doi.org/10.1016/j.foodhyd.2020.106281

Dimova, N. (2003). RP-HPLC analysis of amino acids with UVdetection. Comptes Rendus de l'Academie Bulgare des Sciences, 56(12), 12-75

FAO/WHO Expert Consultation on Fats and Fatty Acids in Human Nutrition, Fats and fatty acids in human nutrition: report of an Expert Consultation, 10-14 November 2008, Geneva (2010).

Gómez-Limia, L., Cobas, N., \& Martínez, S. (2021). Determination of proximate composition, fatty acid profile and total amino acid contents in samples of the European eel (Anguilla anguilla) of different weights. International Journal of Gastronomy and Food Science, 100364. https://doi.org/10.1016/j.ijgfs.2021.100364

Hultin, H. O., \& Kelleher, S. D. (2001). U.S. Patent No. $6,288,216$. Washington, DC: U.S. Patent and Trademark Office.

Iwasaki, M., \& Harada, R. (1985). Proximate and amino acid composition of the roe and muscle of selected marine species. Journal of Food Science, 50(6), 1585-1587. https://doi.org/10.1111/j.1365-2621.1985.tb10539.x

Kaczmarek S., Cowieson A.J., Jozefiak D. \& Rutkowski A. (2013). Effect of maize endosperm hardness, drying temperature and microbial enzyme supplementation on the performance of broiler chickens. Anim. Prod. Sci., 54, 956-965. https://doi.org/10.1071/AN13113
Khan, S., Rehman, A., Shah, H., Aadil, R. M., Ali, A., Shehzad, Q., \& Xia, W. (2020). Fish Protein and Its Derivatives: The Novel Applications, Bioactivities, and Their Functional Significance in Food Products. Food Reviews International, 1-28. https://doi.org/10.1080/87559129.2020.1828452

Klinkesorn, U., Sophanodora, P., Chinachoti, P., Decker, E.A., McClements D.J. (2006). Characterization of spray-dried tuna oil emulsified in two-layered interfacial membranes prepared using electrostatic layer-by-layer deposition. Food Research International, 39 (4), 449-457. https://doi.org/10.1016/j.foodres.2005.09.008

Kris-Etherton, PM, Harris, WS, Appel, LJ \& AHA Nutrition Committee, American Heart Association (2003). Omega3 fatty acids and cardiovascular disease: new recommendations from the American Heart Association. Arterioscler Thromb Vasc Biol., 23, 151-152. https://doi.org/10.1161/01.ATV.0000057393.97337.AE

Mariamenatu, A. H., \& Abdu, E. M. (2021). Overconsumption of Omega-6 Polyunsaturated Fatty Acids (PUFAs) versus Deficiency of Omega-3 PUFAs in Modern-Day Diets: The Disturbing Factor for Their "Balanced Antagonistic Metabolic Functions" in the Human Body. Journal of Lipids, 8848161. https://doi.org/10.1155/2021/8848161

Mol, S., Baygar, T., Varlik, C., \& Tosun, Ş. Y. (2008). Seasonal variations in yield, fatty acids, amino acids and proximate compositions of sea urchin (Paracentrotus lividus) roe. Pharmaceutical Food Analysis, 16(2), 68-74. https://doi.org/10.38212/2224-6614.2363

Özyurt, G., \& Polat, A. (2006). Amino acid and fatty acid composition of wild sea bass (Dicentrarchus labrax): a seasonal differentiation. European Food Research and Technology, 222(3), 316-320. https://doi.org/10.1007/s00217-005-0040-z

Özyurt, G., Durmuş, M., Uçar, Y., \& Özoğul, Y. (2020). The potential use of recovered fish protein as wall material for microencapsulated anchovy oil. LWT, 129, 109554. https://doi.org/10.1111/jfpp.12432

Özyurt, G., Şimşek, A., Karakaya, B. T., Aksun, E. T., \& Yeşilsu, A. F. (2015). Functional, Physicochemical and Nutritional Properties of Protein from K lunzinger's Ponyfish Extracted by the $\mathrm{pH}$ Shifting Method. Journal of food Processing and Preservation, 39(6), 1934-1943. https://doi.org/10.1111/jfpp.12432

Özyurt, G., Gayde, Ç., Aksun, E. T., Durmuș, M., Uçar, Y., \& Bogă, E. K. (2019). The impacts of fish protein isolate addition on the nutritional and quality properties of chicken frankfurter during cold storage $\left(4^{\circ} \mathrm{C}\right)$. Journal of Food Safety and Food Quality, 70 (5), 138-148.

Shaviklo, A. R., \& Etemadian, Y. (2019). Overcoming current challenges in commercial applications of fish protein isolates in food and feed systems: a review. Journal of Food Science and Technology, 56(11), 4775-4784. https://doi.org/10.1007/s13197-019-03966-5

Velasco, J., Dobarganes, M.C., Márquez-Ruiz G. (2020). Oxidation of free and encapsulated oil fractions in dried microencapsulated fish oils. Grasas Y Aceites, 51 (6) 439446. 